\title{
Degradation of leaf litter of five tree species by Perionyx excavatus with relation to their nutrient and anti-nutrient content
}

\author{
Sayantani Pattanayak ${ }^{1}$, Rupa Dasgupta ${ }^{1}$, Partha Pratim Chakravorty ${ }^{1}$, \\ Susanta Kumar Chakraborty ${ }^{2}$ \\ ${ }^{1}$ Department of Zoology, Raja N. L. Khan Women's College, Midnapore, India \\ ${ }^{2}$ Department of Zoology, Vidyasagar University, Midnapore, India \\ Email address: \\ parthapratimchakravorty@yahoo.in (P. P. Chakravorty)
}

To cite this article:

Sayantani Pattanayak, Rupa Dasgupta, Partha Pratim Chakravorty, Susanta Kumar Chakraborty. Degradation of Leaf Litter of five Tree Species by Perionyx excavatus with Relation to their Nutrient and Anti-Nutrient Content. Agriculture, Forestry and Fisheries.

Vol. 3, No. 2, 2014, pp. 128-132. doi: 10.11648/j.aff.20140302.22

\begin{abstract}
The ecological suitability of different leaf litter types in enhancing the biological diversity and micronutrient status in soil needs to be understood for deciding the plant species to be used for afforestration practices. The present research work was done to study the colonization of an epigeic earthworm, Perionyx excavatus in the decomposing leaf litter of five locally important tree species- Cashew, Shal, Mango, Acacia and Eucalyptus up to a period of 90 days. The major nutrient and anti-nutrient chemical parameters of the leaf litters were compared and rates of degradation of the selected nutrient and anti-nutrient parameters were studied in laboratory microcosms. P. excavatus showed maximum colonization for Cashew followed by Shal where both these tree species exhibited comparatively lower anti-nutrient content and significantly higher rates of degradation of the selected nutrient parameters. Lowest colonization by $P$. excavatus was observed in case of Eucalyptus which exhibited highest polyphenol and tannin content and significant lower rates of degradation of all the selected nutrient parameters and hence their utilization in microcosms with $P$. excavatus. The results indicated that lower content of tannins and polyphenols in case of Cashew and Shal can be related to the palatability of these leaf litters and thereby exhibiting maximum colonization by $P$. excavatus. Thus, Cashew and Shal can be considered as suitable tree species for afforestation practices for enhancing nutrient recycling and effective soil conservation.
\end{abstract}

Keywords: Colonization, Leaf Litter, Nutrient Parameter, Anti-Nutrient Parameter, Perionyx excavatus

\section{Introduction}

In terrestrial ecosystems, the major part of the net primary production enters through the detritus based food web litter [1]. Litter decomposition is an important process regulating energy flow, nutrient cycles and structures of ecosystem [2]. Many studies have shown that decomposition is influenced by litter quality, climatic factor and soil biota $[2,1,3,4]$. It is important to understand the key changes in various processes like decomposition and nutrient recycling for sustainable management of forest ecosystems [5]. Afforestation is an eco-friendly practice for soil conservation and environmental management. Different native and exotic tree species are generally used for large scale afforestation and soil conservation. So, the ecological suitability of different leaf litter types in improving biological diversity and micronutrient status in soil needs to be explored. Again, a proper assessment of the functional significance of a mega soil fauna like oligochaete is very pertinent to understanding the mechanism of detritovore feeding guild and fauna mediated mobilization of energy in natural ecosystems. The main objective of the present work was to study the colonization of an epigeic earthworm- Perionyx excavatus in the decomposing leaf litter of five locally important tree species- Acacia (Acacia auriculiformes), Shal (Shorea robusta), Cashew (Anacardium occidentale), Eucalyptus (Eucalyptus citridora) and Mango (Magnifera indica) and to compare the rate of degradation of nutrient and anti-nutrient content of these leaf litters in controlled microcosms. The data has significance in determining suitable tree species for afforestation practices for showing 
maximum palatability of its leaf litter by soil biota.

\section{Materials and Methods}

\subsection{Collection and Culture of Test Specimens}

Perionyx excavatus were collected from shady, cool and moist areas especially organically rich systems like composite pits, domestic and industrial organically rich systems that has never been used for any agriculture or pest control. Hand digging and sorting of soil was done for collection of earthworms [6]. The specimens were identified and brought in plastic bags along with soil to the laboratory.

The earthworms were cultured in the laboratory in earthen pots $(45.72 \mathrm{~cm}$ in diameter and mean breadth $30.48 \mathrm{~cm})$. Finely grounded grassland soil that has never been used for agriculture or pest control was mixed with farmyard manure in the ratio of $1: 1$ and was used as the culture medium [7]. The culture pots were kept inside BOD incubators at $28 \pm 0.5^{\circ} \mathrm{C}$ and an approximate moisture level of 50-60\% was maintained by adding distilled water into the medium. Dried and ground farmyard manure was added as feed every week during the entire period of culture [8].

\subsection{Selection of Leaf Litter}

Leaf litter of the following five different tree species that are common in Midnapore as well as in the state of West Bengal, India were used.

Table 1. Different leaf litters used in the study.

\begin{tabular}{cll}
\hline Serial No. & Common Name & Scientific Name \\
\hline 1. & Acacia & Acacia auriculiformis \\
2. & Shal & Shorea robusta \\
3. & Cashew & Anacardium occidentale \\
4. & Eucalyptus & Eucalyptus citridora \\
5. & Mango & Mangifera indica \\
\hline
\end{tabular}

\subsection{Collection and Preservation of Leaf Litter}

Freshly fallen senescent leaves of the above mentioned tree species were collected in large quantities during the months of January to March, representing the period of highest litter fall. These were properly air dried and stored in labelled polythene container.

\subsection{Determination of the Rate of Colonization}

Open choice experiments were conducted in circular plastic trays containing five different randomly distributed leaf litter pits in smaller petri-dishes inserted into a uniform layer of moist sand bed. Fifty adult age synchronized specimens were released into the tray. The rate of migration and colonization of the specimens were recorded by counting their number in each litter type at 15 day interval up to a period of 90 days [9].

\subsection{Determination of the Chemical Parameters and the Rate of Degradation of the Leaf Litters}

In another set of experiments, microcosms were prepared in small polythene containers by laying moist leaf litter cuttings as the substrate and food source. Fifty adult age synchronized Perionyx excavatus were released into the microcosms. Their numbers were kept constant by replacing dead specimens, if any during observation.

On the $90^{\text {th }}$ day, after retrieving the test soil fauna, leaf litter were properly dried at $50-60^{\circ} \mathrm{C}$ in a hot air oven, grinded and allowed to pass through $72 \mathrm{~mm}$ mesh sieve for estimation of nutrient and anti-nutrient contents according to the following standard methods:

Anti-nutrient parameters - Total lipid and polyphenol [10]; Tannin-Folin Denis Method [11]; Lignin [12].

Nutrient parameters- Total soluble carbohydrate [13]; Reducing sugar [14]; Total protein [15].

\subsection{Statistical Analysis}

The data were analyzed using Excel (version 2007) and SPSS (version 10). Comparison of the data on degradation of nutrient and anti-nutrient content of the different leaf litter between 0 and 90 days were analyzed using ANOVA at $5 \%$ level of probability using SPSS (version 10). Student's ' $t$ ' test was performed to compare the data on nutrient and anti-nutrient contents and to compare the data on rates of degradation between control and experimental sets for each parameter.

\section{Results}

P. excavatus exhibited maximum colonization indicating their feeding preference for Cashew (Anacardium $s p$ ) followed by Shal (Shorea $s p$ ), Mango (Magnifera $s p$ ) and Acacia (Acacia sp) whereas lowest colonization which is indicative of the lowest feeding preference of the test specimens was observed in case of Eucalyptus (Eucalyptus $s p$ ) among all the leaf litters tested (Figure 1).

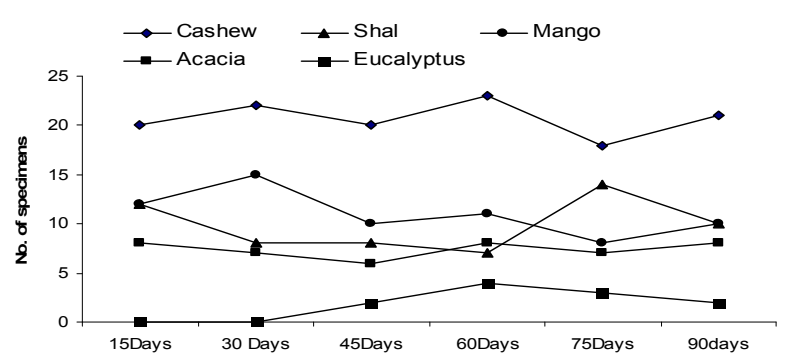

Figure 1. Colonization of P. excavatus in the leaf litter of five tree species.

Nutrient chemical contents of the leaf litters were compared. In case of reducing sugar, total carbohydrate and total protein, highest and lowest contents were observed in the leaf litter of Cashew $(94.23 \pm 0.45,98.03 \pm 0.15$, $88.25 \pm 0.49 \mathrm{mg} / \mathrm{g}$ ) and Acacia (48.13 $\pm 0.15,50.26 \pm 0.30$, $52.56 \pm 0.55 \mathrm{mg} / \mathrm{g}$ ) respectively (Figure 2). 


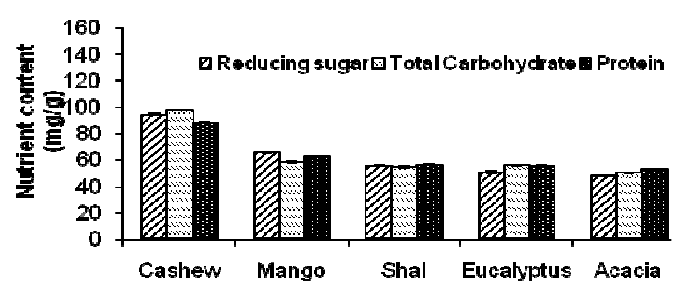

Figure 2. Nutrient content of the leaf litters of five tree species.

In case of anti-nutrient content of the leaf litters, highest polyphenol and tannin were observed in the litters of Eucalyptus (140.0 \pm 0.45 and $112 \pm 0.92 \mathrm{mg} / \mathrm{g}$ respectively) followed by the litter of Acacia (129.73 \pm 0.83 and $107.19 \pm 5.6 \mathrm{mg} / \mathrm{g}$ respectively). Lowest polyphenol and tannin content were observed in the litters of Cashew and Shal $(66.83 \pm 0.2 \mathrm{mg} / \mathrm{g}, 42.2 \pm 0.2 \mathrm{mg} / \mathrm{g})$ respectively. Lipid content was found to be highest in Cashew $(70.7 \pm 0.7 \mathrm{mg} / \mathrm{g})$ and lowest in Shal $(34.9 \pm 0.1 \mathrm{mg} / \mathrm{g})$ (Figure 3).

In case of microcosms with $P$. excavatus, maximum degradation of reducing sugar, total carbohydrate and total protein (\% reduction from initial value) were found to be in Cashew $(89.3,89.73$ and $87.50 \%$ respectively) followed by Shal (74.62, 81.32 and $80.55 \%$ respectively) and Mango (82.88, 79.16 and $77.74 \%$ respectively) in 90 days.
Significant lower rates of degradation of the selected nutrient parameters were observed in Eucalyptus and Acacia. Eucalyptus leaf litter exhibited 51.76, 49.69 and $58.40 \%$ reduction of reducing sugar, total carbohydrates and total proteins whereas for Acacia the percentage decline of the values were recorded as 53.4, 54.91 and $60.99 \%$ respectively.

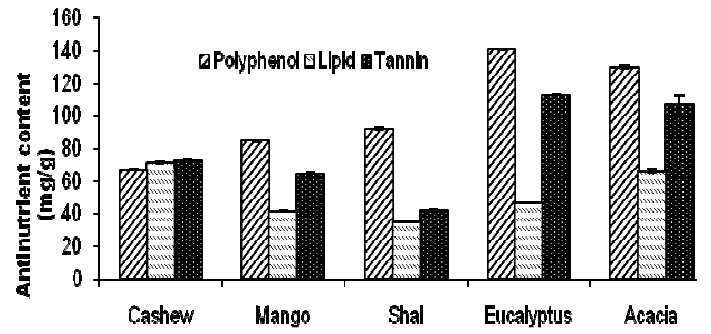

Figure 3. Anti-nutrient content of the leaf litters.

Highest decline in polyphenol, lipid and tannin were noted in Cashew (76.60, 74.70 and $77.23 \%$ respectively) in feeding experiments. Lowest rates of decline of polyphenol content in Acacia (48.90\%) for feeding microcosms and lipid and tannin contents were observed in Eucalyptus (47.89 and $62.65 \%$ respectively).

Table 2. Rate of degradation of the selected nutrient parameters.

\begin{tabular}{|c|c|c|c|c|c|c|c|}
\hline \multirow{4}{*}{$\begin{array}{c}\text { Leaf litter type } \\
\text { Cashew }\end{array}$} & \multirow{2}{*}{$\begin{array}{c}\text { Interval } \\
\text { in days }\end{array}$} & \multicolumn{2}{|c|}{ Reducing Sugar (mg/g) } & \multicolumn{2}{|c|}{ Total Carbohydrate(mg/g) } & \multicolumn{2}{|c|}{ Protein (mg/g) } \\
\hline & & Microcosm control & Microcosm feeding & Microcosm control & Microcosm feeding & Microcosm control & $\begin{array}{l}\text { Microcosm } \\
\text { feeding }\end{array}$ \\
\hline & 0 & $94.2 \pm 0.4$ & $94.2 \pm 0.4$ & $98.0 \pm 0.1$ & $98.0 \pm 0.1$ & $88.2 \pm 0.4$ & $88.2 \pm 0.4$ \\
\hline & 90 & $50.5 \pm 0.3$ & $10.0 \pm 0.4$ & $56 . \pm 0.3$ & $10.0 \pm 0.2$ & $55.0 \pm 4.6$ & $11.0 \pm 0.2$ \\
\hline \multirow[t]{2}{*}{ Mango } & 0 & $65.6 \pm 0.6$ & $65.0 \pm 0.6$ & $58.2 \pm 1.0$ & $58.2 \pm 1.0$ & $62.6 \pm 0.4$ & $62.6 \pm 0.4$ \\
\hline & 90 & $32.7 \pm 0.3$ & $11.2 \pm 0.3$ & $29.8 \pm 0.7$ & $12.1 \pm 0.7$ & $37.6 \pm 0.5$ & $13.9 \pm 0.0$ \\
\hline \multirow[t]{2}{*}{ Shal } & 0 & $55.4 \pm 0.1$ & $55.4 \pm 0.1$ & $54.4 \pm 0.5$ & $54.4 \pm 0.5$ & $56.2 \pm 0.2$ & $56.2 \pm 0.2$ \\
\hline & 90 & $30.3 \pm 0.4$ & $14.0 \pm 0.1$ & $30.6 \pm 0.5$ & $10.1 \pm 0.5$ & $27.5 \pm 0.5$ & $10.9 \pm 1.3$ \\
\hline \multirow[t]{2}{*}{ Eucalyptus } & 0 & $50.5 \pm 0.5$ & $50.5 \pm 0.5$ & $55.6 \pm 0.3$ & $55.6 \pm 0.3$ & $55.3 \pm 0.3$ & $55.3 \pm 0.3$ \\
\hline & 90 & $28.8 \pm 0.40$ & $24.3 \pm 0.5$ & $30.0 \pm 0.1$ & $28.0 \pm 0.2$ & $29.4 \pm 0.3$ & $23.0 \pm 0.6$ \\
\hline \multirow[t]{2}{*}{ Acacia } & 0 & $48.1 \pm 0.1$ & $48.1 \pm 0.1$ & $50.2 \pm 0.3$ & $50.2 \pm 0.3$ & $52.5 \pm 0.5$ & $52.5 \pm 0.5$ \\
\hline & 90 & $25.9 \pm 0.3$ & $22.4 \pm 0.1$ & $30.1 \pm 0.5$ & $22.6 \pm 0.4$ & $26.7 \pm 0.1$ & $20.5 \pm 0.1$ \\
\hline
\end{tabular}

+ Source of variation between leaf litter type, between interval and interaction exhibited $\mathrm{p}<0.05$.

Table 3. Rate of degradation of the selected anti-nutrient parameters.

\begin{tabular}{|c|c|c|c|c|c|c|c|}
\hline \multirow[t]{2}{*}{ Leaf Litter type } & \multirow[t]{2}{*}{$\begin{array}{c}\text { Interval } \\
\text { in days }\end{array}$} & \multicolumn{2}{|c|}{ Polyphenol(mg/g) } & \multicolumn{2}{|c|}{ lipid(mg/g) } & \multicolumn{2}{|c|}{ Tannin(mg/g) } \\
\hline & & Microcosm control & $\begin{array}{l}\text { Microcosm } \\
\text { feeding }\end{array}$ & Microcosm control & Microcosm feeding & Microcosm control & $\begin{array}{l}\text { Microcosm } \\
\text { feeding }\end{array}$ \\
\hline \multirow[t]{2}{*}{ Cashew } & 0 & $66.8 \pm 0.2$ & $66.8 \pm 0.2$ & $70.7 \pm 0.7$ & $70.7 \pm 0.7$ & $72.6 \pm 0.4$ & $72.6 \pm 0.4$ \\
\hline & 90 & $36.0 \pm 0.05$ & $15.6 \pm 0.6$ & $38.7 \pm 0.5$ & $17.9 \pm 0.4$ & $37.6 \pm 0.6$ & $16.5 \pm 0.1$ \\
\hline \multirow[t]{2}{*}{ Mango } & 0 & $84.2 \pm 0.3$ & $84.2 \pm 0.3$ & $41.5 \pm 0.3$ & $41.5 \pm 0.3$ & $64.5 \pm 0.4$ & $64.5 \pm 0.4$ \\
\hline & 90 & $52.1 \pm 0.2$ & $18.1 \pm 0.1$ & $21.3 \pm 0.2$ & $11.7 \pm 0.6$ & $30.3 \pm 0.1$ & $14.4 \pm 0.05$ \\
\hline \multirow[t]{2}{*}{ Shal } & 0 & $91.6 \pm 0.6$ & $91.6 \pm 0.6$ & $34.9 \pm 0.1$ & $34.9 \pm 0.1$ & $42.2 \pm 0.2$ & $42.2 \pm 0.2$ \\
\hline & 90 & $64.3 \pm 0.4$ & $28.3 \pm 0.1$ & $18.2 \pm 0.2$ & $10.7 \pm 0.3$ & $19.1 \pm 0.6$ & $14.1 \pm 0.1$ \\
\hline \multirow[t]{2}{*}{ Eucalyptus } & 0 & $140.7 \pm 0.4$ & $140.7 \pm 0.4$ & $46.0 \pm 0.6$ & $46.0 \pm 0.6$ & $112.6 \pm 0.9$ & $112.6 \pm 0.9$ \\
\hline & 90 & $93.6 \pm 0.6$ & $65.6 \pm 0.6$ & $26.1 \pm 0.2$ & $24.0 \pm 0.1$ & $48.0 \pm 0.2$ & $42.0 \pm 0.1$ \\
\hline \multirow[t]{2}{*}{ Acacia } & 0 & $129.7 \pm 0.8$ & $129.7 \pm 0.8$ & $66.0 \pm 0.9$ & $66.0 \pm 0.9$ & $107.1 \pm 5$ & $107.1 \pm 5.6$ \\
\hline & 90 & $75.8 \pm 0.7$ & $65.5 \pm 0.6$ & $18.2 \pm 0.6$ & $16.5 \pm 0.1$ & $47.8 \pm 0.3$ & $30.5 \pm 0.5$ \\
\hline
\end{tabular}

+ Source of variation between leaf litter type, between interval and interaction exhibited $\mathrm{p}<0.05$.

The rates of degradation of the nutrient and anti-nutrient parameters of all the leaf litters were significantly higher in microcosms with the test specimen than in comparison to control. 


\section{Discussion}

Several researchers have noted the role of epigeic earthworms in the degradation of leaf litter. A relationship between litter characteristics and their palatability by soil fauna has been reported by several authors $[5,9,16]$. Studies have indicated that earthworm species prefer certain litter type over others and palatability of the litters were dependent on the initial $\mathrm{C}: \mathrm{N}$ ratio and the content of anti-nutrients [17]. Initial polyphenol and liginin content of the leaf litters were found to be directly related to their palatability and assimilation by different soil fauna like earthworms. Decomposition rates were also found to be negatively related to the anti-nutritional content like lignin [18].The critical role of $P$. excavatus, a major soil fauna in nutrient recycling was observed in the present study with significant higher rates of degradation of the chemical constituents of the leaf litters in experimental microcosms than in case of control microcosms. $P$. excavatus exhibited maximum colonization for Cashew and Shal respectively whereas lowest colonization of the test specimen was observed in case of Eucalyptus and Acacia. Assessment of anti-nutrient content of the litters exhibited comparatively higher polyphenol and tannin content in Eucalyptus followed by Acacia which can be related to the lower rate of colonization and rates of degradation of the nutrient and anti-nutrient parameters of these leaf litters. Maximum colonization in Cashew and Shal with higher rates of degradation of the chemical parameters of these leaf litters can again be related to their lower anti-nutrient contents, viz polyphenol and tannin leading to higher palatability $[17,18$, $19,20]$. So availability of easily assimilable resources in the litter enhance decomposition and litter containing high proportion of anti-nutrients like tannin, polyphenol and lignin adversely affect the feeding preference inhibiting the nutritional efficacy of these species. Suppression of the feeding rate by the test specimen results in lower rate of degradation of the leaf litters which ultimately inhibits the nutrient recycling process in the particular ecosystem [9].

\section{Conclusion}

It was concluded from the present study that Cashew and Shal can be considered as suitable tree species in afforestation practices for enhancing nutrient recycling, soil conservation and environmental management. Again considering the economic importance of plantation of Cashew in lateritic regions, plantation of Cashew should be given at most importance.

\section{Acknowledgements}

S. Pattanayak, R. Dasgupta and P. P. Chakravorty would like to thank the Principal, Raja N. L. Khan Women' College for providing with laboratory facilities and UGC-CPE, DST-FIST for providing necessary funds.

\section{References}

[1] D. A. Wardle, P. Lavelle, "Linkages between soil biota plant litter quality and decomposition," in Driven by Nature: Plant Quality and Decomposition, G. Kadisch and K. E. Giller, Eds. London, CAB international,1997.

[2] C. Wa-Chendorf, U. Irmler and H. P. Blume, " Relationship between litter fauna and chemical changes of litter during decomposition, in Driven by Nature: Plant litter Quality and Decomposition, K. E. Giller, Eds. Wallingford, CAB International, 1997.

[3] L. Heneghan, D. C. Coleman, D. A. Crossley Jr, and X. M. Zou, "Nitrogen Dynamics in decomposing chestnut oak (Quercits prinus L.) in mesic temperate and tropical forest,"Appl. Soil. Ecol., vol. 13, pp. 169-175, 1999.

[4] G. Gonzalez and T. R. Seast-edt, "Soil fauna and plant litter decomposition in tropical and subalpine forests", Ecology, vol .13, pp. 955-964, 2001.

[5] S.E . Attigon, D. Weibel, T. Lachat, D. Sinsin, P. Nagel and R. Preveling, "Leaf litter breakdown in natural and plantation forests of the Lama forest reserve in Benin," Appl. Soil. Ecol., vol. 27, pp. 109-124, 2004.

[6] D. C. Coleman, D. A, Crossley Jr, and P. F. Hendrix, "Fundamentals of Soil Ecology, $2^{\text {nd }}$ edition, San diago, C.A, Academic Press, 2004.

[7] S. A. Ismail, "Vermicology-The Biology of Earthworms", India, Orient Longman, 1997.

[8] R. Dasgupta, P. P. Chakravorty and A. Kaviraj, "Studies on the relative toxicities of five insecticides on epigeic earthworm, Perionyx excavatus," Bull. Env. Contam. Toxicol., vol. 85(1), pp. 83-86, 2010.

[9] S. N. Roy and V. C. Joy, "Dietary effects of non nutrients in the leaf litter of forest trees on assimilation, growth and tissue composition of the detritovore soil arthropod Anoplodesmus sausserei (Humb.) (Polydesmida: Diplopoda)," Appl. Soil. Ecol.,vol. 43, pp. 53-60, 2009.

[10] H. G. C. King and G. W. Heath, "The chemical analysis of small samples of leaf material and the relationship between the disappearance and composition of leaves," Pedobiologia, vol. 7, pp.192-197, 1967.

[11] S. Sadasivam and A. Manickam, "Biochemical Methods for Agricultural Science,” New Delhi, Wiley Eastern Ltd., 2006.

[12] F. E. Brauns, "Tappi standard method $\mathrm{T} 13$ for the determination of Lignin," The chemistry of Lignin, New York, Academic Press, 1952.

[13] M. Dubois, K. A. Giues, J. K. Hamilton, P. A. Rebers and F. Smith, "Calorimetric determination of sugars and related substances," Anal. Chem. ,vol. 28, pp. 351-356,1956.

[14] D. L. Morris, "The quantative determination of carbohydrates with Dreywood's anthrone reagent," Science, vol. 107 , pp. $254-255,1948$.

[15] O. H. Lowry, N. J. Rosenbrough, A. L. Farr and R. J. Randall, "Protein measurements with the Folin-Phenol reagent," J. Biol. Chem., vol. 193, pp. 265-275,1951.

[16] T. D. Oliveira, S. Hattenschwiler and I. T. Handa, "Snail and millipede complementaity in decomposing Mediterranean forest leaf litter mixtures," Funct. Ecol., vol. 24, pp. 937-946, 2010. 
[17] N. B.Hendriksen, "Leaf litter selection by detritovore and geophagous earthworms" Biol Fer soil, vol10, pp 17-21, 1990.

[18] S. E Hobbie, P. B. Reich, J. Oleksyn, M. Ogdachi, R. Zytkowiak, C. Hale and P. Karlolewski, " Tree species effects on decomposition and forest dynamics in a common garden" Ecology, vol 87(9) pp 2288-97, 2006.
[19] M. S. Patricio, L. F. Nunes and E. L. Pereira, "Litterfall and litter decomposition in chestnut high forest stand in northern Portugal," Forest Sys., vol. 21(2), pp. 259-271, 2012.

[20] M. B. Johansson, B. Berg and V. Meentenmeyer, "Litter mass loss rates in late stages of decomposition in a climatic transect of pine forests," Can. J. Bot., vol. 73, p.p 1509-1521, 1995. 